\title{
A Struggle over Recognition and Nonrecognition: The Internationalization of the Abkhaz State University
}

\author{
Bruno Coppieters (1) \\ Vrije Universiteit Brussel, Belgium \\ Email: Bruno.Coppieters@vub.be
}

\begin{abstract}
The Abkhaz State University (ASU) is internationally isolated, despite its cooperation with universities in Russia. Georgia combines its refusal to recognize Abkhaz statehood with a policy of nonrecognition of its university, which sets the direction for other countries. But the Abkhaz policies of nonrecognition are also to be taken into account. Abkhazia opposes any form of internationalization of the ASU generating closer ties with Georgia. The article examines how the Georgian and Abkhaz policies of nonrecognition hamper the internationalization of the ASU within the European educational space. It explores a conflict on recognition and nonrecognition of status and identity, where status does not refer exclusively to statehood. In the field of higher education, European integration involves a large number of state and nonstate actors in 49 countries and a wide variety of forms of recognition and nonrecognition, ranging from the certification of individual qualifications and the publication of lists of unrecognized universities, to the setting up of joint educational programs. This integration process is largely state driven but based on the principle of the institutional autonomy of universities. Using the ASU as a case study, the way that policies on nonrecognition affect status in the field of higher education is examined.
\end{abstract}

Keywords: Abkhazia; recognition; Georgia; university; conflict transformation

\section{Introduction}

Throughout the Soviet period, Abkhaz and Georgians were involved in a conflict on the constitutional status of Abkhazia. The dispute became politically more acute in the 1970s. Georgia was a union republic of the USSR, and Abkhazia an autonomous republic, subordinated to Georgia. The Abkhaz opposed this formal dependence. The Georgian authorities, by contrast, wanted to preserve the status of the Abkhaz autonomous republic as subordinated to Georgian state institutions. This conflict was expressed in a dispute on status and identity in higher education. The Abkhaz protested at the lack of a state university in their republic, and not until the end of the 1970s did the Soviet central authorities in Moscow give in to their demand, as part of a number of concessions made to the Abkhaz population. In an enhancement of status that strengthened Abkhaz national identity, the Abkhaz State University (ASU) was established in 1979. The university's official purpose was to give the multinational population of this autonomous republic, and of Western Georgia in general, better access to higher education (Abkhaz State University 2021a; Ofitsial'nyy sayt Prezident Respubliki Abkhaziya Sergey Bagapsh 2008). To this end, the ASU was divided into a Russian, a Georgian, and an Abkhaz branch.

\footnotetext{
(C) The Author(s), 2021. Published by Cambridge University Press on behalf of the Association for the Study of Nationalities. This is an Open Access article, distributed under the terms of the Creative Commons Attribution licence (http://creativecommons.org/licenses/by/4.0/), which permits unrestricted re-use, distribution, and reproduction in any medium, provided the original work is properly cited.
} 
The Soviet reforms failed, however, to satisfy Abkhaz demands for an upgrading of the status of their republic. Moreover, they angered the Georgian community in Abkhazia, which protested against policies privileging the Abkhaz, and the 1980s saw a nationalist mobilization of both communities. In these conflicts over status and identity, higher education played a key role (Anchabadze 1999, 132-133). The Georgian community strove to have the Georgian branch separated from the ASU, and - in line with this demand - in 1989, the Georgian government decided to open a branch of Tbilisi State University (TSU) in Sukhum(i), the capital of Abkhazia. This decision was strongly opposed by the Abkhaz. According to Jurij Anchabadze, "the problem of the TSU branch in Sukhum became the main object around which the activity of both sides' national movements centred" $(1999,133)$.

The lack of agreement on university policies between the two main national communities in Abkhazia triggered an escalation of the conflict. In June 1989, the dispute led to violent clashes in Sukhum(i). This was followed by a military mobilization in Georgia itself. After the dissolution of the Soviet Union, armed formations from Georgia entered Abkhazia in August 1992, leading to outright war. The Abkhaz gained the upper hand, and in September 1993, the Georgian troops had to retreat from Abkhaz territory, and the majority of the Georgian inhabitants there were forced to flee.

Abkhazia's 1994 Constitution declared the republic to be sovereign, and in 1999, Abkhazia declared its independence. After the war between Russia and Georgia in August 2008, Abkhazia was recognized by Russia, Venezuela, Nicaragua and a few other countries, but it remained by and large isolated on the international scene. Today, this is even more the case for the ASU: it cooperates with Russian universities, but it does not benefit from state-to-state cooperation with the other countries that have diplomatic relations with Abkhazia. It has failed to establish cooperation with other universities located in the European educational space, which covers the territory of all Council of Europe (CoE) members.

This article focuses on the isolated position of the ASU. The lack of internationalization is not just a function of the absence of recognition, but it also results from an active policy of nonrecognition. The article explores whether and how this lack of integration could be regarded as a by-product of the nonrecognition of Abkhaz statehood by the governments of Georgia and most other countries. The Abkhaz policy of nonrecognition must also be taken into account. The Abkhaz authorities oppose any form of international academic cooperation that shows even the slightest sign of Georgian involvement, or of generating more closeness with Tbilisi. They would, for instance, refuse any proposal that would make the participation of the ASU in the EU's mobility program Erasmus + dependent on the requirement that its status as a university be defined as part of the Georgian educational space. These observations prompt the following question: how do the Georgian and Abkhaz policies of nonrecognition hamper the internationalization of the ASU within the European educational space?

The main aim of this article is (1) to explore the policies of recognition and nonrecognition by state and nonstate actors toward a university that is itself not formally a state institution and (2) to see how these policies regarding the status of the ASU affect its internationalization. Recent literature in international law (Berkes 2017; Hamid 2020; Wittke 2020) and political science (Fabry 2012; Ker-Lindsay 2012; Coppieters 2018; Bouris and Papadimitriou 2020 Wydra 2020) on the recognition and nonrecognition of statehood has broadened our understanding of the legal implications of a lack of recognition of political entities - and the way international law addresses such problems - as well as of the nature of negotiations and agreements where one of the participants or signatories is not recognized by the other as a sovereign state, but where there is nonetheless a mutual recognition of rights and duties. The latter is the case in particular in ceasefire and trade agreements with contested states (Visoka and Doyle 2015; Coppieters 2019b; Hsieh 2019). The questions addressed in international law refer to the legal validity of such agreements and the particular problems that arise during their implementation, as compared to classic interstate agreements. Political science research addresses the motives for coming to such 
agreements and their significance for recognition processes in a state-centered international order. The studies in each of these disciplines demonstrate a strong aspiration to bridge the gap separating one type of disciplinary knowledge from the other.

The present article extends this body of research on relations with contested states. It broadens the examination of processes of mutual recognition and nonrecognition that do not imply the recognition of statehood. It examines processes of recognition and nonrecognition that involve not only actors that are considered - or that claim - to be states but also nonstate actors such as universities, university associations, and accreditation agencies. The links between recognition, nonrecognition, and processes of conflict transformation, as analyzed by authors such as Strömbom (2014) regarding protracted conflicts on identity, will also be addressed.

Abkhazia, whose main university has been chosen as a case study here ${ }^{1}$ is prominent in the literature on the EU's policies of engagement in contested states (Caspersen 2018; Noutcheva 2020), but its university has not attracted scholarly attention despite the fact that it is the second largest institution in Abkhazia after the armed forces. This lack of research is even more surprising when one considers that opinions in the literature differ as to the effectiveness of the Abkhaz institutions (Prelz Oltramonti 2020,98), and that education is one of the main basic services to be provided for a population. With regard to education, academic research has dealt exclusively with the Abkhaz policies affecting Georgian schools in Gal/i (Comai and Venturi 2015). The significant exception is the comparative study by Thomas de Waal and Sabine von Löwis (2020) on the internationalization of higher education in Abkhazia, Transnistria, and Northern Cyprus. ${ }^{2}$

The body of this article is divided into four sections. Before examining Georgian and Abkhaz policies, we begin by clarifying the meaning of the concepts of recognition and nonrecognition as they relate to both statehood and other types of status, as well as the way these two concepts are used in political science and international law. We then proceed to the second section, which examines the relationship between the recognition and nonrecognition of statehood and the recognition and nonrecognition of universities in the European educational space. This relationship is at the heart of the European Higher Education Area (EHEA) that encompasses the activities of numerous state and nonstate actors throughout the territory of the Council of Europe (CoE). Here, we explore how disputes on statehood affect policies of recognition and nonrecognition of universities and their internationalization. The third section examines the particular features of the Georgian and Abkhaz policies of recognition and nonrecognition, including in the field of higher education. It also explains the marginalization of the ASU within the European educational space. The fourth section is devoted to an empirical case to illustrate the points raised in the preceding sections. It goes into the problems of establishing a sustainable form of cooperation between EU universities and the ASU. From 2012 to 2015, the author coordinated an EU-funded project that enabled an exchange of lecturers between the EU and Abkhazia. This project achieved its primary objectives, but it failed to secure any substantial follow-up in the ensuing years or improve the integration of the ASU into the European educational space. The reasons for this are examined, as well as a number of alternative options. The article's conclusions go into the theoretical and practical implications of this analysis. Regarding the latter, it explores the reasons why it may be in the interests of the conflicting parties to reform their recognition and nonrecognition policies in order to overcome the ASU's international isolation, and it assesses the scope for compromise in this regard.

\section{Policies of Recognition and Nonrecognition}

An examination of the multifaceted concepts of recognition and nonrecognition of statehood and of other types of status benefits from the endeavors of political science and international law. Regarding statehood, both of them agree that its recognition is a political decision with legal effects. From the perspective of international law, recognition of statehood creates rights and duties within the international community. It has to take certain legal principles into account, such as the 
principle of nonrecognition, which forbids the recognition of a political entity as a sovereign state where its existence is due to, or accompanied by, severe breaches of international law (Lauterpacht 2013). There may, for instance, be legal impediments to the recognition of a particular state created on an occupied territory.

The recognition of statehood is also central in studies on secession in political science. A crucial issue for independence movements struggling for the recognition of a right to statehood is the attainment of sovereign equality with other nations. The recognition of such status by the international community strengthens national identity. Status and identity are described as two major sources of self-esteem and dignity for a nation (Fearon 1999; Coppieters 2019b). Certain forms of nonrecognition, conversely, may be considered a lack of esteem or respect. Such a derogatory position is to be found, for instance, in the argument that an independence movement or an entity claiming statehood is no more than a puppet of a foreign power.

In international law, the principle of sovereign equality excludes a basic differentiation between different types of statehood because this would imply different rights and duties. Political science, by contrast, operates with such a differentiated concept of statehood. It offers a wide range of concepts to describe entities whose statehood is not recognized internationally. The two most common terms used are a "de facto state" (Pegg 1998) and a "contested state" (Geldenhuys 2009). The former stresses the presence of intrinsic characteristics of statehood, such as the exercise of control over a territory and its population, and the capacity to establish relations with other powers by remaining constitutionally independent. The latter, by contrast, indicates that the claims of a particular political entity to possess such characteristics of statehood are strongly disputed both in international diplomacy and within the scholarly community (Coppieters 2019b). The concept of a contested state has been chosen for this article because it emphasizes more strongly the interaction with the international community and the disputed nature of statehood in the absence of recognition. Both of these aspects are central when investigating the degree of internationalization of a university such as the ASU, which is located on a disputed territory.

Policies of recognition refer to the status and identity that the parties accept to be attributed to themselves or to the other. This also includes the status and identity of nonstate institutions under their control. A central government opposing secession strives, for instance, to have its sovereign authority over the breakaway territory recognized by the international community. It considers that territory to be a region, a province, or another kind of subordinated entity, and it wants such status to be recognized internationally as well.

Policies of nonrecognition, by contrast, refer to the specific status and identity with which the parties do not accept to be associated - or do not accept to be attributed to the other. For a central government countering secession, its policies of nonrecognition refer, for instance, to its refusal to negotiate with the breakaway party on equal terms or to accept an agreement on the status question that would threaten its own supremacy. It further may refuse to recognize the status of nonstate organizations such as companies or universities in the breakaway territory. Contested states, on the other hand, strive to have their independence recognized and, when it comes to their nonrecognition policies, they can refuse, for instance, to accept a settlement where they would have subordinated status. A contested state may also refuse an agreement with the central government that implies any oversight on its part of nonstate institutions - such as universities - on the disputed territory.

Policies of recognition are affirmative, whereas policies of nonrecognition display rejection or resistance. In certain cases, however, it is possible to define recognition policies in terms of nonrecognition. This is the case, for instance, with a state or a contested state that aims to be recognized as sole sovereign over a territory, an objective that directly implies the nonrecognition of the same claim made by any other state or contested state. In many other cases, however, policies of recognition and nonrecognition cover very different actions and situations - consequently, they need to be clearly distinguished from one another. Two central governments may, for example, defend similar policies of recognition - striving, for instance, to be accepted internationally as the 
highest authority over a disputed territory - but have totally different policies regarding their type of opposition to attempts of third parties to facilitate the integration of this territory into the world economy. They may oppose a type of membership in a multilateral organization that would imply full statehood, but they may alternatively also oppose any form of membership. There can also be a situation in which one of the conflict parties hardens its nonrecognition policies without any modification of its policies of recognition, or vice versa, where one party changes its policies of recognition without any substantial shift in its policies of nonrecognition. To give an example of the latter, a central government defends a policy of nonrecognition whereby it refuses representative status to the contested state in a multilateral organization. As a final settlement, however, it accepts - albeit reluctantly - a federation in which both parties would have equal status as federated entities. It then replaces this policy of recognition with a new policy, whereby it strives for a unitary state in which the breakaway entity would only have a limited form of autonomy - without, however, changing its policy of nonrecognition regarding membership to multilateral organizations.

Policies of recognition and of nonrecognition express what the conflicting parties are ready to accept, which is likely to change in function of the relationship of forces or in function of their perception of the costs of the nonresolution of the conflict. Parties can then, for instance, accept for themselves or for the other party - a status that goes against their former policy of nonrecognition in exchange of clear benefits in terms of their policies of recognition. The parties are then ready to accept a trade-off between their respective policies of recognition and nonrecognition and to engage in a compromise with the other party. This implies acceptance of the costs included in the compromise deal and mutual recognition. Such an attitude can, however, come at additional political costs, when the contradiction between the two policies turn into political disputes within the government or with the political opposition.

Agreements between conflicting parties are based on an acknowledgment that they have common interests. This is the case with ceasefire and trade agreements - the former in halting an armed conflict, and the latter in facilitating the exchange of goods. This requires an arrangement regarding the mutual recognition of status. A central government opposing secession can sign a ceasefire or a trade agreement with a contested state without accepting the other party as a sovereign state. But the two types of agreement still imply a recognition by the central government that the de facto authorities of the disputed territory exercise a certain amount of control over the territory either militarily or in terms of trade flows. Mutual recognition is also at the origin of the rights and obligations of the two parties spelled out in the agreements. In the case of a ceasefire agreement, mutual recognition can also imply a mutually accepted role for third parties in overseeing its implementation, as observers or peacekeepers. A trade agreement can explicitly give the de facto authorities the right to issue documents to facilitate the exchange of goods, such as customs papers or certificates of origin. International law deals with all of these forms of recognition. Legal documents circumvent the question of a recognition of statehood by linking the bearer of such rights and obligations to the exercise of a particular function. This results in terms such as "nonstate armed groups," "customs territories," "economic entities," "trade entities," and "fishing entities." Such forms of mutual recognition - where one of the parties is not recognized as a state by the other contracting party or parties - can be described as asymmetric. It still implies the recognition of a certain status for the contested state and may thus strengthen its national identity. This is to be acknowledged as a necessary political cost by the central government, a feature of the trade-off between its policies of recognition and nonrecognition.

In an international context where there is no highest authority, external support for one of the parties can decisively strengthen its status and identity claims. But it must also be taken into account that external parties always have their own policies of recognition and nonrecognition, which are not necessarily in line with those of the party they are supporting (Coppieters 2019b, 17).

The following section will analyze the extent to which a description of a dispute on status in terms of policies on the recognition and nonrecognition of status and identity can be fruitfully 
applied, to not only contested states but also universities on their territory, in particular within the European educational space.

\section{International Recognition and Nonrecognition of Universities in the European Educational Space}

Recognition and nonrecognition are key to all university activities. Academic research is inextricably linked to scientific criticism, which is expressed in conferences and peer reviews. Regarding education, universities assess and recognize the achievements of their students through the awarding of diplomas. Students, for their part, are asked to evaluate their lecturers. In addition to these forms of recognition and nonrecognition of educational performance, which take place mainly within universities, the international level is also to be taken into account. Students expect their diplomas not only to be accepted by employers on the national labor market but also to grant them international mobility. This requires guarantees of quality assessment (QA) and the development of international educational standards.

QA agencies in charge of the accreditation of study programs at universities have to be independent of the state for reasons of efficiency and credibility, even if they are initiated and supported by national governments. These agencies also have to demonstrate their own compliance with international educational standards through external review processes. Universities that strive for the recognition of their overall performance in research and education have to accept additional forms of external evaluation by specialized bodies.

In addition, there are forms of mutual recognition among universities, which sign Memoranda of Understanding (MoUs) and other kind of agreements with one another. These agreements are designed to cover joint projects in education and research or even "strategic" forms of collaboration. And universities have set up their own international associations. All these activities, relevant to describing the degree of internationalization of universities, have recognition and nonrecognition at their core. Before examining the internationalization of the ASU, it is necessary to look at the overall institutional set-up in the field of higher education - first internationally and then in Europe.

The International Association of Universities (IAU) was founded in 1950. Its membership is open to universities and other institutions of higher education. Its members come from more than 130 countries, making it the most representative global organization in its field (Anonymous1 2013). The IAU's membership and organizational rules respect the institutional autonomy of universities. The IAU has a close partnership with UNESCO, which has always been very active on issues relating to the international recognition of qualifications through interstate treaties and conventions. The IAU has its own governing bodies, which represent its membership. All highereducation institutions may apply to join it, including universities in disputed territories. The Eastern Mediterranean University (EMU) in Northern Cyprus and Tamkang University (TKU) in Taiwan, for instance, are among the 640 members of the IAU - although the country reference for the EMU is, however, Turkey, not Cyprus. The IAU's association with UNESCO, a specialized agency of the United Nations, requires that the country reference of Taiwanese universities indicate that they belong to China. The category "China-Taiwan" is then used in this context (International Association of Universities 2021a).

The IAU provides information on the systems and credentials of higher-education institutions worldwide. It collects information from local higher-education authorities and accrediting institutions in 196 countries and territories. The IAU implements a very strong policy of nonrecognition of so-called "bogus" universities by making information about these institutions public. It is, furthermore, actively engaged with the problems confronting higher-education institutions in war-torn countries, where it is difficult - if not impossible - to apply standard accreditation rules. The IAU publicizes documentation on some 19,400 institutions in a World Higher Education Database (WHED) (International Association of Universities 2021b), which universities use as one of the means at their disposal to assess the qualifications of foreign students. 
European universities also have their own regional body. With more than 800 members in 48 countries, the European University Association (EUA) covers the entire territory of Council of Europe members. Seventeen million students are registered at EUA member universities (European University Association 2021). The EUA addresses a broad spectrum of educational policy issues, with both QA and qualifications central to its work. With respect to the governance of universities, it upholds the principle of institutional autonomy as a core value. Its membership includes universities located on territories that are outside of the control of recognized states, such as the EMU.

The IAU and the EUA are the products of interuniversity cooperation. The international integration of higher education in Europe is, however, mainly state driven. The Bologna Process and the European Higher Education Area (EHEA) (European Higher Education Area and Bologna Process 2021) are the products of intergovernmental cooperation, in which the European Commission (EC), the Council of Europe (CoE), and the member states of the CoE play a key role. The EHEA's goals include the recognition of study periods and qualifications, based on the Lisbon Recognition Convention, and a shared understanding of QA (Piro 2016).

The role of state authorities was particularly prominent in drafting the Lisbon Recognition Convention of 1997. The states party to this convention have set up national information centers, which belong to the European Network of National Information Centres (ENIC Network), created by the CoE and UNESCO (ENIC-NARIC Networks 2021), and the vast majority of them are also taking part in the National Academic Recognition Information Centres (NARIC) Network, formed by the European Union. These national centers provide information to students, universities, and ministries about quality assurance, accreditation procedures, and the recognition of foreign diplomas and other qualifications. Often, they also provide recognition of foreign qualifications, thereby giving access to the national labor market.

The European Association for Quality Assurance in Higher Education (ENQA), for its part, is responsible for developing QA in Europe, together with national centers for educational quality enhancement and other actors (ENQA 2021) Here, too, national authorities play a key role in setting up the institutions needed to regulate university integration into the EHEA.

The institutional complexity of this integration process can be illustrated by a description of Georgia's participation in the Bologna Process. In 2010, Georgia set up a National Center for Educational Quality Enhancement (NCEQE) as part of the ENIC/NARIC network and, at the same time, as the only authorized quality-assurance agency. This body, which is a member of the ENQA, provides for institutional authorization and program accreditation in higher education, and Georgian universities are legally required to work in compliance with its QA standards (National Erasmus+ Office [NEO] Georgia 2021). The National Erasmus+ Office (NEO) Georgia supports the implementation of the Erasmus+ program. This whole set-up facilitates compliance by individual Georgian universities with European and Georgian requirements in order to participate in programs such as Erasmus+.

It can be concluded from this overview that the international activities of universities - and primarily the raising of their educational standards, their accreditation, and their international mobility schemes - are strongly regulated by the state on whose territory they are operating. National educational authorities significantly increased their role in the recognition procedures through European integration. In the Bologna Process, however, institutional autonomy remains a basic principle in the governance of higher education (Pandey 2004). This does not mean that higher education is in fact independent of the state or the government. On the contrary, the principle, which is closely associated with the principle of academic freedom, aims at counterbalancing the strong role of state authorities in European education policies - and the universities' high degree of dependence on national state authorities - by stressing the autonomy of universities and other agencies. The principle applies equally to so-called "state universities." Institutional autonomy means free decision-making and operational freedom. It aims at flexibility to meet societal needs, at an optimal allocation of resources in research and education, and at an 
authoritative quality assessment (Pandey 2004). Regarding institutional autonomy in universities, four different areas may be distinguished: organizational autonomy, financial autonomy, staffing autonomy, and academic autonomy. The actual degree of autonomy from the state can be measured in each of these areas, which are, at the same time, interrelated, with the result that a restriction in one area of autonomy has a negative impact on another (Estermann 2015, 28-32).

Our research question concerns the internationalization of the ASU, defined here as an "intentional process of integrating an international, intercultural or global dimension into the purpose, functions and delivery of post-secondary education, in order to enhance the quality of education and research for all students and staff, and to make a meaningful contribution to society" (De Wit, Hunter, Howard, and Egron-Polak 2015, 29). The objectives of an internationalization of higher education closely resemble those of university reform overall, and achieving them may even be regarded as a precondition for improving the quality of higher education. This is particularly the case for external QA or international accreditation processes. The internationalization of higher education is also closely related to conflict transformation, a process that is understood in this article as favoring compatibility between the positions of the conflicting parties regarding their status and identities. ${ }^{3}$ It is also a learning process where the conflict parties increase their capacity to address the causes and consequences of divergent positions and to make these positions mutually more acceptable. One of the main aims of the European educational space is to promote the compatibility of different national systems. This is directly relevant to conflict transformation when it concerns cooperation between universities across conflict lines. Any institutional cooperation between universities requires, furthermore, an agreement on rights and obligations, both as a sign of respect and esteem and as a means of encouraging trust building. The participation by students from conflict regions in a common educational space further increases the opportunities for mutual dialogue with students who hold different views on the nature of such conflicts.

Before examining the degree to which the ASU has managed to internationalize, it is necessary to operationalize the concept of internationalization. The challenge for the ASU is to meet the following seven criteria: (1) the establishment of a robust system of quality assessment (QA), recognized internationally through the external accreditation of its study programs; (2) the international recognition of its diplomas, both on the international labor market and by other universities; (3) the establishment of bilateral relations with other universities; (4) membership of international university associations; (5) the provision of necessary travel documents for staff and students; (6) the awarding of individual scholarships for study abroad, as well as participation in mobility programs such as Erasmus + that enable students to travel for study as part of the curriculum at their home university; and (7) the establishment of an administration that will support the university's internationalization effectively.

As already indicated, the internationalization of higher education in Europe is closely intertwined with a state-driven process of integration. This means that the nonrecognition policies of national authorities may seriously hinder the internationalization of a university on a disputed territory. Regarding the first criterion for internationalization, no contested state in Europe has managed to create its own QA agencies, with the only exception of Kosovo (EQAR 2021). Many of the universities in Northern Cyprus, however, still enjoy the benefits of the ENIC/NARIC network, thanks to their accreditation by the Turkish Council of Higher Education. This facilitates the acceptance of university diplomas from Northern Cyprus by other universities in the EU and the creation of joint study programs (Eastern Mediterranean University 2021a; Eastern Mediterranean University 2021b). So it is not only the type of nonrecognition policy adopted by governments resisting secession but also the policies of patron states, and the openness of other universities to international cooperation, that play a crucial role in a university's participation in the European educational space. Moreover, university associations can also be involved: the EUA can offer universities in disputed territories a voluntary external QA - under the Institutional Evaluation Programme, which is recognized externally. A QA under this program has been conducted at the EMU, for instance (Anonymous2 2020). 
The acceptance of diplomas from universities on disputed territories constitutes the second criterion of their internationalization. The access to regulated professions is a national competence in European countries, but universities can in principle decide autonomously to register students with diplomas from universities on disputed territories for further studies at their institution. This autonomy is also relevant for cooperation with universities in disputed territories, in line with the third criterion. Regarding the fourth criterion, international university associations can likewise decide autonomously whether or not to extend membership to universities in disputed territories, as both the IAU and the EUA have done in certain cases. Regarding the fifth criterion, the refusal of state authorities to accept travel documents from contested states negatively affects the mobility of staff and students. In some cases, however, this hurdle can be circumvented if the authorities of the contested states adopt a pragmatic position. The Northern Cypriot authorities, for instance, do not oppose their own citizens applying for a Cypriot passport, which allows their staff and students to travel to all EU countries. The sixth criterion, on the provision of individual scholarships for study abroad, generally depends on state support. The contested states themselves do not have the financial means to aid the internationalization of their universities in this way, but their students have in some cases received access to Erasmus + or - as in the case of students from Northern Cyprus - to scholarship funding provided by the EU or individual European states. Regarding the EU mobility program, universities from Northern Cyprus are fully excluded from it, owing to resistance from Cyprus, but Moldova has agreed to the participation of Transnistrian students in Erasmus $+{ }^{4}$ - one of the main outcomes of the OSCE-led negotiations with the Transnistrian leadership. The seventh criterion concerns the willingness and ability of universities on contested territories to create the means to establish relations with other universities, something that may be affected positively or negatively by the policies of their own government.

It may therefore be concluded that for a university on a disputed territory confronting a policy of nonrecognition by the central government, the major difficulties will be getting international acceptance of its quality assessment system and obtaining external accreditation (criterion 1); providing travel documents for its staff and students (criterion 5), and accessing individual scholarships for study abroad as well as international mobility programs such as Erasmus+ (criterion 6). Universities confronted with such policies of nonrecognition are not helpless, however. The European educational sphere is polycentric, and universities on disputed territories with a strong policy of recognition can achieve substantial results. This has been seen in particular with some Northern Cypriot universities, such as the EMU, whose internationalization policies have achieved considerable positive results according to these criteria. The active recognition policy of this state university managed, with the active support of its government and Turkey, to overcome the strong nonrecognition policy of the Cypriot central government. Its strong "entrepreneurial spirit" allowed it to establish itself against all odds on the international scene. As we will see in the next section, the ASU is not one of the successful examples. The reasons why are worth examining.

\section{The Georgian and Abkhaz Policies of Recognition and Non-Recognition and the Internationalization of the Abkhaz State University ${ }^{5}$}

The Georgian claim that Abkhazia is occupied by Russia implies that any recognition of Abkhaz independence is in breach of the legal principle of nonrecognition and, in particular, the prohibition on recognizing a state created under occupation as lawful. Georgia combines this principled position with a willingness to engage with the Abkhaz population. The Georgian engagement policies focus on benefits for individuals living in the two disputed territories, Abkhazia and South Ossetia, especially in terms of health services and education. Students from there can apply for administrative and financial support to study in Georgia. Under Georgian policies, students can make use of simplified procedures to have their Abkhaz or South Ossetian diplomas certified (OC Media 2018). ${ }^{6}$ Once registered at a Georgian university, they can participate in international student exchanges under the Erasmus+ program. This Georgian offer attracts students almost 
exclusively from the Gal(i) region, a Georgian-populated part of Abkhazia from which relatively few young people go to study at the ASU.?

The first characteristic of the Georgian initiatives is that they are addressed to individual citizens, not to the Abkhaz state authorities or the ASU. Tbilisi claims that its stance allows for reconciliation with the Abkhaz population without compromising on the principle of nonrecognition. Another characteristic is that the Georgian initiatives cannot take place on Abkhaz territory. That would require authorization by the local authorities. However, it would be impossible for the Georgian government to request such authorization, given that it considers these authorities to be illegitimate.

Four different Georgian ministries are involved, either directly or indirectly, in the nonrecognition policies toward Abkhazia as they affect higher education. The one most involved is the State Ministry for Reconciliation and Civic Equality, whose very existence reflects the position that Abkhaz and South Ossetian issues are primarily a domestic and not a foreign policy matter. The ministry has a role in preparing and implementing Georgian legislation on occupied territories, and it designs governmental initiatives targeting the populations of the two territories, including in the field of education. The title "state ministry" indicates that its tasks are of the highest rank in the Georgian government. Its proposals regarding higher education in Abkhazia require coordination with the Ministry of Education. The Georgian Ministry of Internal Affairs performs security tasks at the former administrative border with Abkhazia - the "occupation line" in official Georgian discourse - whereas the Ministry of Foreign Affairs incorporates Georgian nonrecognition policies into its overall diplomatic activities.

The ASU has between 2,500 and 3,000 students $^{8}$ - for a population of somewhere between 200,000 and 250,000 (de Waal and von Löwis 2020, 5). Under the Abkhaz authorities' structures, the ASU is a publicly funded institution that is formally autonomous in its policies. The Ministry of Education is not involved in higher education. The president of Abkhazia is head of the university's board. This does not imply any involvement in the day-to-day management of the university, although the president may intervene on issues he/she considers important. Internationalizing higher education is one of the tasks of the Ministry of Foreign Affairs.

Through statements (Kove 2018) and practical policies, the Abkhaz authorities have made it clear what status they do not wish to be attributed to Abkhazia or to Georgia in relation to Abkhazia. Their nonrecognition policies severely constrain any ASU initiative regarding cooperation. The Abkhaz authorities reject any project focusing on bilateral relations with Georgia that could be interpreted as an attempt to favor the reintegration of Abkhazia into Georgia - including, therefore, any cooperation between the ASU and Georgian universities. They also find it unacceptable to make use of Georgia's international agreements in the field of higher education. Any projects - including multilateral ones - that might make the country somehow dependent on decisions made in Tbilisi have to be rejected.

In December 2020, the Abkhaz president, Aslan Bzhania, published foreign policy guidelines delineating the official policies of recognition and nonrecognition. According to this document, international cooperation has to take place on the basis of "equality and mutual respect" (Prezident Respubliki Abkhaziya 2020). This requires a "normalization" of mutual relations with Georgia. In its policies of nonrecognition, Abkhazia opposes any interference in its internal affairs. Regarding higher education, Abkhazia is interested in establishing relations with EU countries and would in particular appreciate having "access to European education."

The Georgian authorities, for their part, have never described the ASU as an illegal entity. Nor are there any official publications in which the word "university" is put between quotation marks when referring to the ASU, as is the case with Cypriot documents referring to universities in the north of that island. In fact, the Georgian authorities have recognized the ASU as one of their own by including it in the list of Georgian universities sent to the $\mathrm{IAU}^{9}$ for the "World List of Universities and Other Institutions of Higher Education" (International Association of Universities 2006). The 2010 edition of the International Handbook of Universities, which is also edited by the IAU, even indicates that the ASU is "under the jurisdiction of the Ministry of People's Education of Georgia" 
(International Association of Universities 2010, 1310). This reference is no longer included in the 2011 or later editions of this handbook or in its electronic database.

That the ASU features in a list of accredited universities is not contrary to a nonrecognition policy that claims that such institutions are still formally under the jurisdiction of the central authorities, despite the loss of factual control by the central government. Its inclusion can be seen as part of a Georgian policy of formal appropriation: the handbook indicated that the university was located on "Tsereteli Street," as it was known before the 1992-1993 war - a tribute to the famous Georgian writer - and not on "University Street," as it is now called. ${ }^{10}$ The creation by the Georgian authorities in 2010 of the NCEQE as the only Georgian-authorized quality-assurance agency made it, however, impossible to accredit the ASU without following proper procedures, so this university could no longer be included in any official list of universities "recognized" by Georgia.

The ASU is a member of both the Eurasian University Association (Abkhaz State University 2021b; Yevraziyskaya assotsiatsiya universitetov 2021), which is based in Moscow, and the Academic Union (AU), which is located in Oxford. ${ }^{11}$ The former association is made up of 142 universities from the Commonwealth of Independent States (CIS), and the latter mainly of universities in Turkey, Northern Cyprus, and the former Soviet Union. Neither of these institutions, however, is a real alternative to the IAU or the European University Association (EUA) ${ }^{12}$ when it comes to the geographical scope of their membership base, exchange of information, or the political impact they have on the European educational space.

Regarding bilateral academic agreements, the position of the ASU is in line with that of the Abkhaz authorities, who regard the recognition of Abkhaz statehood as the optimal condition for such cooperation. The ASU has a clear preference for interuniversity cooperation that comes under state-to-state agreements as well as where the Abkhaz MFA takes the lead in establishing such relations - such as the cooperation with Moscow State University and other universities in Russia. But of the other states that currently recognize Abkhazia - Venezuela, Nicaragua, Syria, and Nauru - none has the capacity to support substantial bilateral cooperation in the field of higher education.

In 2014, the Russian authorities offered 290 scholarships to Abkhaz students, giving them the opportunity to obtain a degree at Russian universities (RIA Novosti 2014). In 2017, 1,692 students from Abkhazia were studying in Russia, 782 of them on a scholarship (Tass 2017). The main rationale for this policy is no different from other cases of educational diplomacy: to improve future relations with the countries of origin of the students, ${ }^{13}$ to promote the educational values of the awarding authorities, and to offer educational support to partner countries (Mäkinen 2016). In what is a frequent outcome of international student mobility, many of these students remain in Russia after completing their studies.

Russian support for Abkhaz students has benefits for the ASU: a large proportion of the ASU's teaching staff has a degree, or even a $\mathrm{PhD}$, from a Russian university. But Russian scholarships do not improve the ASU's internationalization directly. As with Georgian scholarships, it is individual students they support.

ASU diplomas are accepted in Russia. A number of students from Abkhazia, including ASU students, study at universities in Turkey and - although far fewer of them - in the EU and other European countries. At the administrative level, owing to different rules on the recognition of diplomas, when it comes to universities in countries that do not recognize Abkhazia, it is easier for a student with a degree from the ASU to gain admission to postgraduate studies (a specialized master's degree program, for instance) than it is for a student with an Abkhazian secondary school diploma to be accepted to an undergraduate program (bachelor's degree). The United Kingdom has made a few scholarships available to Abkhaz students for postgraduate studies. ${ }^{14}$

The conditions for acceptance of ASU diplomas by universities in countries that do not recognize Abkhazia vary. In Germany, the Central Office for Foreign Education (Zentralstelle für ausländisches Bildungswesen $[\mathrm{ZAB}]$ ) of the Standing Conference of the Ministers of Education and Cultural Affairs of the Länder (Kultusminister Konferenz) is the national NARIC and ENIC information center. It has created a database that makes a distinction between recognized and 
nonrecognized universities (anabin - Das Infoportal zu Ausländischen Bildungsabchlüssen 2021). Although theoretically autonomous when it comes to making decisions on application procedures, German universities work with this list to evaluate diplomas. A substantial shift took place in Germany regarding the status of the ASU. The 2013 database still indicated that the ASU was officially a nonrecognized university. This meant that it was not accredited by the home country that is, Georgia. This classification would generally have led universities in Germany to reject any applications by students with an ASU degree to study there for a master's degree (Anonymous3 2013). ${ }^{15}$ But the issue is now addressed differently. The 2021 database no longer contains such an unequivocal assessment. The ASU is still described as Georgian, but the database further indicates that the ASU is located on a breakaway territory of Georgia. As a consequence of this re-ranking, it is now in a category of institutions "for which no clear statement can be made" (anabin - Das Infoportal zu Ausländischen Bildungsabchlüssen 2021), and despite the lack of accreditation, German universities are invited to make a careful examination of individual applications from students with an ASU diploma.

The Flemish NARIC/ENIC information center did not create its own database, but Flemish universities ${ }^{16}$ use that of the central ENIC/NARIC - a joint initiative by the European Commission, the Council of Europe, and UNESCO (ENIC-NARIC Networks 2021) - which includes full information on the universities accredited by its members. They also have the IAU handbook at their disposal, in which the ASU is no longer listed as a recognized university. Here, too, the general rule applies: when it comes to accepting diplomas from other universities for the registration of students for graduate studies, universities are free to make their own decisions. Flemish universities have diverging practices regarding the acceptance of ASU diplomas held by students wishing to register for a master's program. One might ask for advice from the director of its master's program, whereas another would require an official statement from the Abkhaz Ministry of Education that the ASU is accredited in Abkhazia. Interestingly, the fact that such a declaration would come from a state not recognized by Belgium would not invalidate it. A third Flemish university would ask for confirmation from the Russian Ministry of Education that their universities recognize the ASU degree in question, thereby circumventing the problem of Belgium's nonrecognition of Abkhazia. A fourth would pay special attention to the use of the European Credit Transfer and Accumulation System (ECTS), which allows the home university to take into account credits awarded by a foreign university as an indicator of quality and reforms in line with the Bologna Process (Anonymous4 2013). All four universities would stress that such decisions have to be made on the basis of authoritative information and in the best interests of the applicant.

The uncertainty facing Abkhaz students who apply to universities in Germany or Flanders is similar elsewhere in Europe. Broader research among universities would reveal an even greater diversity of practices concerning decisions on documents - generally, it is up to the administration of each particular university to decide how flexible it will be.

Abkhaz have to obtain student visas for countries that do not recognize their passports. But each country has a different position on how its nonrecognition policies regarding Abkhazia apply to travel documents, and often it is an ad hoc decision that is made about them. In addition, scholars from the ASU wishing to participate in international conferences cannot be sure whether they can obtain the necessary travel documents, which makes it difficult for them to take part to international academic activities.

The ASU is one of the very few universities in Europe that has not invested in an administrative unit responsible for international contacts. It does have a small secretariat for this specific purpose (Abkhaz State University 2021b), but all communication is handled directly by the rector and the vice-rector. This absence of administrative capacity, together with the lack of involvement in IAU or EUA activities, and nonparticipation in the Bologna Process, Erasmus+, or the EHEA make it difficult for the ASU to acquire formal expertise on the internationalization of higher education and international experiences in university reform. 
It may be concluded that the ASU has achieved little in terms of the seven internationalization criteria mentioned above, especially when it comes to forms of internationalization where the university is dependent on decisions made by national governments. The ASU does not participate in international activities or discussions regarding QA, and it is not accredited externally (criterion 1). Its staff and students cannot apply for the Erasmus+ mobility program. The Russian government does provide a significant number of university scholarships for Abkhaz students, but this benefits the ASU only indirectly (criterion 6). Visa applications often encounter insurmountable problems (criterion 5). The ASU also does not meet these criteria for forms of internationalization that depend on autonomous choices of European universities. Its students are uncertain about the chances that their diploma will be accepted by universities outside Russia (criterion 2). The ASU's failure to internationalize is largely due to a lack of effort and capacity. The ASU has not even created an effective university administration for its internationalization (criterion 7). It did not apply for membership of the IAU or EUA, despite the positive experience of these two organizations with universities on disputed territories (criterion 4). The ASU's existing relations with Russian universities have resulted largely from state-to-state relations, and it failed to establish bilateral relations with other universities on its own initiative (criterion 3 ).

This lack of internationalization can be directly linked to the lack of university reform. Unlike other universities in the post-Soviet space, including Russia, the ASU did not make any great effort to restructure its educational system. There is also no real debate on this issue, either among the public or in the Abkhaz parliament or government. Some aspects of internationalization - such as establishing QA standards, external accreditation, and foreign language education ${ }^{17}$ - are, however, inconceivable without a thorough curriculum review and revision. At the same time, university reform necessitates considerable organizational resources, particularly for QA, which can only be provided through internationalization.

Russia has never followed the example of Turkey with respect to Northern Cypriot universities by including the ASU on its own list of accredited universities. This could in principle facilitate the acceptance of ASU diplomas in other countries, in the same way that diplomas from better universities in Northern Cyprus are now accepted, but this form of "deep integration" would be contrary to the Abkhaz interest ${ }^{18}$ because it would be an additional element raising questions about the independent status of Abkhazia. It would also go against Russia's claim that it does not intend to annex that territory. Moreover, not many students from Russia go to Abkhazia to study, which is unlike the case of Northern Cyprus, whose universities are attended by large numbers of students from Turkey. Russia therefore does not have the same interest in a formal accreditation of the ASU as Turkey does with respect to universities in Northern Cyprus.

\section{An EU-Funded Project for Lecturer Mobility between the ASU and Universities in the EU 2012-2015}

The policies of the EU and its member states on engagement in Abkhazia after the 1992-1993 war did not focus on higher education. This did not change until, in the aftermath of the 2008 Georgian-Russian war, the EU decided to develop initiatives directed specifically at Abkhaz youth as part of a general policy of conflict transformation. The EU felt that student exchanges would be beneficial for dialogue and trust building. The EU Special Representative for the South Caucasus and the Crisis in Georgia, Philippe Lefort, managed to convince the Georgian authorities of the need for direct educational links between the ASU and universities in the EU. As part of this initiative, between 2012 and 2015, the EU funded a project for the exchange of university lecturers between the EU and Abkhazia - a project which, it was hoped, would promote the inclusion of the ASU in the European educational space. An additional objective of this first experience in lecturer mobility was to prepare follow-up student exchange projects. Although none of the conflict parties were opposed in principle to exchanges between the ASU and universities in the European Union, none of them were prepared to give the project their full support. 
The project came up against several obstacles, such as the absence of an administrative department at the ASU in charge of internationalization, as indicated above. Another major issue was Abkhazia's mistrust of the EU, which meant that it was unwilling to accept a strong EU presence there, due to the EU's unconditional support for Georgia's territorial integrity. But on the Georgian side, there was also a certain amount of suspicion of the EU's policy of nonrecognition and engagement. The EU combines its refusal to recognize Abkhaz statehood with a readiness to engage with the Abkhaz population (Coppieters 2019a; Fischer 2010). This policy is similar to the Georgian policy of engagement as described above, but it nonetheless reflects different interests and perceptions. First, the EU generally supports a more flexible approach to the implementation of projects in Abkhazia. Unlike the Georgian government, which does not involve the Abkhaz authorities in its engagement projects, the EU has to make sure that its projects are accepted by the local authorities if they are to be implemented. Second, the European Commission, the Council, and the European External Action Service - in contrast to the European Parliament and some individual EU member states - do not link their support for Georgia's territorial integrity to the claim that Abkhazia is occupied by Russia. This means that their policies of nonrecognition are not based on the legal principle of nonrecognition, which, in turn, gives them more latitude in interpreting and applying this principle than Georgia likes. Tbilisi can voice its opposition to EU engagement projects in Abkhazia, and it is kept informed about the implementation of such projects, but it is not involved in their daily management. This lack of complete control creates a certain disquiet. The 2012-2015 lecturer mobility project was moreover considered more sensitive than other EU projects owing to the establishment of links with a major Abkhaz institution: Tbilisi was not fully confident that this would not contradict its own policies of nonrecognition.

The first sign of mistrust came from the Abkhaz side in the very first weeks of the project's implementation. In February 2013, when the first course had just started at the ASU's Department of International Relations, President Ankvab decided to put it on hold. One of the reasons for this was that he had not been properly informed beforehand about the preparation of a Memorandum of Understanding $(\mathrm{MoU})$. His not having been informed is not surprising, given that cooperation between universities and the organization of lectures does not have to appear on the agenda of a head of state. But the Abkhaz president is also ex officio chair of the ASU board, and he did not conceal his distrust of any form of EU presence on Abkhaz territory. The Abkhaz government had already taken restrictive measures toward other projects supported by the EU. The authorities argued that the interruption of the courses at the Department of International Relations had been decided within the framework of the overall monitoring of the activities of international organizations and NGOs, whereas the students participating in the course were told that the decision had been made for security reasons.

A discussion about the president's decision to put the courses on hold started up at the ASU and in Abkhaz social media (Polandov 2013). Some participants considered that education did indeed constitute a security issue for Abkhazia, but the majority were critical of this decision. Some even found it out of line that their president should have intervened in the way he did. President Ankvab had to address the issue at two successive weekly press conferences (Shariya 2013). He declared that he did not question the need to establish educational links between the ASU and universities in the EU but that he was not satisfied with a project that only envisaged sending staff from EU universities to teach at the ASU. Instead, he wanted an exchange of lecturers. This was a face-saving measure because such a proposal could have been put forward and included in the MoU at a much earlier stage, without interrupting the course. The final version of the MoU and an Agreement on the Exchange of Lecturers between the ASU and the Vrije Universiteit Brussel (Free University of Brussels) was drafted in August 2013.

Trust was not fully reestablished, however. At no point did the university leadership of the ASU give practical support to the idea of establishing educational links with EU universities or to follow-up projects. Nor was central administrative support provided. The Department of International Relations decided unilaterally to halve the number of students attending the courses, 
even when it was pointed out that a new application to the EU for any follow-up project regarding lecturer mobility could not justify the required financial support if there were only about 12 students attending each of the courses.

Once the MoU was signed, the Georgian authorities strongly denounced it. They did not oppose cooperation between universities per se but they opposed its formalization. ${ }^{19}$ They insisted that cooperation with Abkhazia could involve only individual students and scholars, as is generally the case for Georgian engagement policies, and that a formal agreement with an Abkhaz institution would be considered "creeping recognition." Despite this criticism, the project did move forward, and it was finalized without additional Georgian objections (European Commission and High Representative of the European Union for Foreign Affairs and Security Policy 2015, 10). But for several years, it seemed impossible to launch any follow-up project in cooperation with the ASU.

The Georgian authorities assumed that the recognition of a university located on a disputed territory would gradually facilitate the recognition of the state controlling that territory. Such a conception of recognition is not based on international law. In order to be legally valid, recognition of statehood has to be clearly expressed, in opposition to the assumption of a "creeping recognition." Also, interuniversity agreements do not have legal implications for disputes on sovereignty. But the concept of a "creeping recognition" does have political significance. Here, it expresses the concern that recognizing an Abkhaz university that is not accredited in Georgia could be seen politically as a sign of acceptance of Abkhazia's de facto independence. This would go against the Georgian policy of nonrecognition.

The Bologna Process stresses the institutional autonomy of all universities, including so-called "state universities." 20 The Georgian denial of the right of foreign universities to sign an MoU with a university on the disputed territory of Abkhazia, as well as the intervention by the Abkhaz president in the organization of university courses, on the other hand, express the view that universities can be regarded as controlled by the state. The difficulty with regarding universities as autonomous entities derives in part from the fact that public universities are largely dependent on government funding and policies. Moreover, the title "state university" - one that is still held by major public universities in Georgia and Abkhazia, such as the ASU - has a positive connotation. In the Soviet Union, a republic's right to have its own state university was even considered one way of exercising its right to national self-determination. Consequently, we see the point argued before - that recognition of universities is traditionally perceived as an intrinsic part of the conflict over the recognition of Abkhaz statehood and identity.

Georgian opposition to any formalization of interuniversity cooperation through contractual relations has serious repercussions on the EU's efforts to support the internationalization of higher education in Abkhazia. The EU has been unable to fund follow-up projects that would be based on contractual relations with the ASU. This, in turn, made it more difficult to forge sustainable interuniversity links with the ASU. University cooperation requires a certain degree of formalization, ranging from the organization of exams by guest lecturers to the organization of activities over several years. The lack of a formal agreement entails the risk that joint projects may have to be constantly renegotiated, leaving them vulnerable to constant politicization.

No less important for interuniversity cooperation than the creation of sustainable links is the necessity to avoid discriminatory policies. This also requires a certain formalization of the cooperation. A nondiscriminatory clause is traditionally included in any interuniversity MoU. This is highly relevant for Abkhazia, where ethnic discrimination is considered an important political issue, including in domestic politics. ${ }^{21}$ It is also an issue at the ASU, where the Department of International Relations - whose students are almost exclusively of ethnic Abkhaz descent - has up to now been the main beneficiary of visits by foreign lecturers. The lack of formal guarantees of nondiscriminatory policies in any cooperative arrangement with the ASU is another consequence of Georgian nonrecognition policies.

The formalization of interuniversity cooperation is, finally, a necessary condition for successful integration into the European educational space. This space relies on autonomous interuniversity 
cooperation and on an active role played by the state authorities. Regarding EU-funded projects, universities are contractual agents twice over: first with the EU, and then with each other. In Erasmus+ mobility programs, for instance, universities are contractual agents in the implementation of educational policies for the enhancement of qualifications and student mobility, and, at the same time, they are autonomous agents in their cooperation with other universities. The creation of effective international frameworks for educational cooperation by the authorities of different states, and the autonomous functioning of universities, can therefore be described as two sides of the same coin. And each of them requires a formalization of the contractual relationship - a condition that cannot be ignored when a university is located on a disputed territory.

Among the potential follow-up projects envisaged for the teacher mobility project, the participation in Erasmus + activities by Abkhaz students, or even their university, ranked high. In the long term, the inclusion of the ASU in Erasmus + had to be seen as far more sustainable for its integration into the European educational space than a succession of tailor-made projects. There are three main advantages of the Erasmus framework for student exchanges, as compared to specific teaching or exchange projects: First, it is based on contractual relations between the universities and the EU that are completely transparent and do not require lengthy negotiations between the parties - an advantage in a situation where even educational programs are easily politicized on the basis of interests that have nothing to do with educational values. Second, the selection of students for Erasmus + mobility is relatively effective. The fact that a good knowledge of the language of instruction at EU universities is a precondition for participation in these exchanges would necessarily motivate Abkhaz students of all disciplines to acquire language skills. Third, from the perspective of the EU, it would make more sense to support student exchanges with the ASU through a program that it has specifically created for the purpose of student mobility.

Participation by the ASU in the Erasmus framework did not seem feasible, however. There were intensive discussions between ministries and agencies in Georgia - the Ministry of Reconciliation and Civic Equality, the Ministry of Education, and the National Centre for Educational Quality Enhancement - about the conditions under which it could accept participation in Erasmus+ mobility schemes by Abkhaz students and by the ASU (Anonymous5 2013 and 2014). The option of a "conditional accreditation" of the ASU by Georgian authorities has been referred to in this context, but it has never materialized. This is also the case for the idea of a consortium of Georgian universities and the ASU that would participate in the Erasmus+ program. The Abkhaz authorities, for their part, formulated no proposal of their own. Consequently, neither of the two sides has managed to come up with a proposal on the integration of the ASU into European mobility programs that both could consider negotiable.

\section{Conclusions:Theoretical and Practical Implications}

The literature in international law and political science on recognition in conflicts on secession deals with ceasefire and trade agreements where one of the parties to the agreement claims a statehood that the other refuses to recognize. Despite this asymmetry in perception and status among the conflicting parties, these agreements imply a mutual recognition of rights and obligations. This assumes an acknowledgment that each of them controls a certain territory and its population, which is a precondition to fulfilling the requirements of the agreement. This research into asymmetric types of recognition and nonrecognition of status in conflicts on secession is extended in this article to the European educational space, where status refers to educational achievements.

In the context of a conflict on secession, ceasefires and trade agreements result from the mutual recognition of states - or entities claiming to be states - in a specific functional domain. In processes of recognition or nonrecognition of status in the European educational space, the situation is more complex regarding the nature of the actors. Like the international community of states, the European educational space is not regulated by one single authority. The creation and integration of this space is state driven, but it also involves civil society actors. This space has been created by the 
educational policies of the Council of Europe (CoE), its member states, and the European Commission, as well as by universities, university associations, and specialized educational agencies. All of these actors are involved in a broad spectrum of recognition and nonrecognition, ranging from the certification of individual qualifications to the setting up of joint educational programs.

Our analysis of the isolated position of the ASU within the European educational space stresses the point that the internationalization of a university located in a disputed territory is a multifaceted process entailing various decisions made largely - but not entirely, and often indirectly - by national authorities. On the positive side, the ASU does have some cooperation with Russian universities. This happens, however, in the framework of state-to-state relations. The large number of scholarships provided by the Russian authorities for Abkhaz students who wish to complete a full university curriculum at a Russian university benefits the internationalization of the ASU, but only indirectly. A large proportion of the ASU staff has a degree from a Russian university. The most crucial factors affecting the ASU's isolation are Georgia's policies of nonrecognition of Abkhaz statehood, which put severe constraints on the issuing of travel documents for ASU staff and students and on the access of the ASU to the Erasmus+ mobility program. Georgian policies also affect the recognition of ASU diplomas negatively, even if universities remain autonomous in their decision to register ASU students.

Nevertheless, the ASU has not made any major efforts in those fields of internationalization where it could make a substantial difference, despite the fact that any active policy of recognition of its educational achievements would surely be met by Georgian countermeasures. Potential initiatives it could have taken include creating administrative capacity to establish international relations, establishing bilateral cooperation with other universities outside Russia, joining the two main international university associations - the IAU and EUA - and setting up an external QA system in line with the experience of universities in Northern Cyprus. The ASU's policies of recognition of its educational achievements and status may therefore be considered weak. The fact that the ASU is not involved in university reform is a further factor to be taken into consideration because such a policy would favor - or even necessitate - initiatives in the field of internationalization. The nonrecognition policies of the Abkhaz authorities impose additional constraints on the ASU's internationalization. They prevent Abkhaz participation in international educational frameworks any time there is even the slightest risk that they might create more closeness with Georgian counterparts or that Georgian authorities might be involved.

The failure of the ASU to integrate into the European educational space has negative consequences for Abkhazia. The ASU's lack of compatibility with other universities with respect to its study programs, along with its lack of external QA, puts severe constraints on its capacity to enhance its educational achievements in line with European standards. Its lack of internationalization also has negative consequences for Georgia, whose refusal to facilitate the integration of the ASU into the European educational space consolidates an exclusive Russian presence. Tbilisi's policies of nonrecognition furthermore sacrifice the interests of ASU students to interests of the state - in particular, to the ambition of reunification. This contradicts the Georgian policy of reconciliation. The isolation of the ASU further weakens the Georgian claim that the combination of a policy of nonrecognition of Abkhaz statehood with a policy of engagement would allow the whole population of Abkhazia to benefit from Georgia's European integration. It also goes against the EU's attempt to achieve a change of position by both parties through conflict transformation.

The cost of the current policies for all sides leaves some leeway for a reorientation. The changes required from the sides would generally involve their showing both greater flexibility in their policies of nonrecognition and more active - but at the same time more moderate - expectations with respect to the policies of recognition. A more tolerant attitude by the Georgian authorities to the presence of the ASU in the European educational space would strengthen Tbilisi's claim to be recognized as acting in the best interests of the whole population of Abkhazia, not only of the ethnic Georgians. In case of Abkhazia, such a presence would require an acceptance that an external QA of 
the ASU - or the university's participation in international mobility activities - necessarily involves debates in which the voices of the Georgian authorities and universities will have to be heard.

A revision of the current policies requires that both sides make a positive cost-benefit calculation. This is not easy to achieve given that the benefits of the policies of recognition of one party - such as the integration of the ASU in the Erasmus network (from the Georgian perspective) or closer links between Abkhaz and Georgian universities (from the Abkhaz perspective) - are perceived as a cost by the other party. Both parties, moreover, have to take the mobilization of domestic opposition against such changes into account. Consequently, the total cost may be substantial. Any transformation of the relationship between the sides in the field of education therefore depends on broader strategic decisions to be made by the two sides.

Georgia and Abkhazia signed several ceasefire agreements during and in the aftermath of the 1992-1993 Georgian-Abkhaz war. The 2008 Georgian-Russian war also ended with such an agreement. There has been an ongoing heated discussion in Abkhazia and Georgia about the possibility of a trade agreement and about the hurdles that need to be overcome in this respect (Mirimanova 2018). Ceasefire agreements refer to the armed forces, and trade agreements have to address the question of customs. They require the inclusion of official representatives of the contested states. As indicated above, international law has developed a specific vocabulary to prevent the inclusion of de facto authorities in such agreements from amounting to a recognition of statehood, so agreements may refer, for example, to nonstate armed groups, a trading entity, or a fishing entity. It would be possible to develop a similar term for the educational authorities of contested states - and to refer to them as representing an "educational entity," indicating specific rights and obligations - with the aim of including them in multilateral arrangements without any recognition of statehood. Such a step toward the de facto authorities of Abkhazia would be very useful, but it is not a necessary condition for the ASU's participation in the European educational space, for which a formal agreement involving the Abkhaz authorities is not necessarily a requirement either. Arrangements can, in fact, be based on the institutional autonomy of universities - one of the basic principles of European integration in higher education.

Acknowledgments. I wish to thank Rustam Anshba, Thomas de Waal, Michael Gaebel, Tomáš Hoch, Sebastian Relitz, Catherine Woollard, and the anonymous reviewers for their critical comments about this article; and Lauren Brombert and Veronica Kelly for the language corrections.

Disclosures. None.

\section{Notes}

1 This article does not deal with the privately funded Sukhum Open Institute, which counted 449 students in 2018 (de Waal and von Löwis 2020, 5 and 11).

2 Salima Dzhikirba and Sebastian Relitz (2020) wrote an informative policy paper on higher education in Abkhazia.

3 The concept of conflict is here understood as an incompatibility between the positions of the conflict parties on their identities and interests. Positive conflict transformation happens when positions are becoming more compatible, and a conflict may be considered resolved when it allows substantial cooperation and common decision-making. See Coppieters 2012, 278. On conflict transformation in the context of the Georgian-Abkhaz dispute, see Wils, Hopp, Ropers, Vimalarajah, and Zunzer 2006.

4 The Taras Shevchenko University in Tiraspol (also known as Transnistrian State University) participates in Erasmus+ mobility programs (de Waal and von Löwis 2020, 23).

5 The information in the following section is largely based on discussions with academics, officials, and NGO members in Abkhazia and Georgia, in the framework of an EU-funded exchange project between the ASU and universities in the EU, which was referenced in the introduction, and which is analyzed in more detail in the next section. These discussions aimed at identifying the practical obstacles for university cooperation and student mobility. 
6 All of the 140 program participants from Abkhazia applying for such support for the academic year 2019/2020 were from the Georgian-populated Gal/i region. See Civil.Ge 2019.

7 In 2017, only 89 students from the Gal/i region studied at the ASU (Hammarberg and Grono 2017, 63).

8 In 2018, 2,564 students, according to de Waal and von Löwis (2020, 5), and 3,000 students in 2021, according to the website of the ASU (Abkhaz State University 2021a).

9 This information was provided by the Georgian authorities to the IAU, not by NGOs or other sources. The IAU establishes university credentials on the basis of information "from national higher education authorities, governmental agencies and national academic bodies" (International Association of Universities 2021b).

10 According to Abkhaz interlocutors, this appellation is one more example of the "Georgianization" of Abkhazia in Soviet times.

11 The Academic Union is located in Oxford but is not associated with its university.

12 The abbreviation EUA is used by both the European University Association and the Eurasian University Association.

13 For additional information on the number of Russian-educated members of the Abkhaz executive and legislative, see Gerrits and Bader 2016.

14 Other EU countries have offered scholarships on an ad hoc basis.

15 These officials would use the anabin database to make a decision, and in their view, it was unlikely that their decision would diverge from the advice found in the anabin database.

16 Education is an exclusive competence of the Belgian communities, which are federated entities. In the case of Flanders, it is a competence of the Flemish Community.

17 On initiatives regarding German- and English-language education in Abkhazia, see Olson and Sovakar 2018a and 2018b. See also Conciliation Resources 2016.

18 On the motives of patron states and their clients to avoid deep integration, see Kolstø 2020, 142.

19 The argument either that the ASU was located on an occupied territory or that the status of occupation would be a legal impediment for interuniversity cooperation - as it is heard, for instance, in Ukraine regarding universities in the Crimea - was not used.

20 On university autonomy in Georgia, see Jibladze 2017. See also Chakhaia and Bregvadze 2018.

21 On the human rights situation in Abkhazia in 2018-2019, see the report of the Abkhaz Ombudsperson for Human Rights (Shakryl 2019).

\section{References}

Abkhaz State University. 2021a. "Istoriya." https://www.agu.site/en/about/ (Accessed July 6, 2021).

Abkhaz State University. 2021b. "International Department." https://www.agu.site/en/about/administration/1344.html (Accessed July 6, 2021.)

anabin - Das Infoportal zu Ausländischen Bildungsabchlüssen. 2021. "Institutionen.” http://anabin.kmk.org/no_cache/filter/ institutionen.html (Accessed July 6, 2021.)

Anchabadze, Jurij. 1999. "History: The Modern Period.” In The Abkhazians, edited by George Hewitt, 132-146. Richmond, UK: Curzon.

Anonymous 1. 2013. IAU official. Interviewed by author, May 31. Paris.

Anonymous2. 2020. EUA official. Interviewed by author, August 6. Brussels.

Anonymous3. 2013. Officials of the registration offices of two German universities. Telephone interviews by author, March. Anonymous4. 2013. Officials of the registration offices of four Flemish universities. Telephone interviews by author, March. Anonymous5. 2013 and 2014. Georgian officials. Interviewed by author, 2013-2014. Brussels and Tbilisi.

Berkes, Antal. 2017. “'Status-Neutrality' of International Organizations: A Mission Impossible with Regard to Self-Proclaimed Separatist Entities?” European Society of International Law, Conference Paper Series, Conference Paper No 2/2017. https:// papers.ssrn.com/sol3/papers.cfm?abstract_id=3045259 (Accessed July 8, 2020.)

Bouris, Dimitris, and Dimitris Papadimitriou. 2020. "The EU and Contested Statehood in Its Near Abroad: Europeanisation, Actorness and State-Building." Geopolitics 25 (2): 273-293.

Caspersen, Nina. 2018. “Recognition, Status Quo or Reintegration: Engagement with de facto States.” Ethnopolitics 17: 373-389. 
Chakhaia, Lela, and Tamar Bregvadze. 2018. "Georgia: Higher Education System Dynamics and Institutional Diversity." In 25 Years of Transformation of Higher Education Systems in Post-Soviet Countries, edited by Jeroen Huisman, Anna Smolentseva, and Isak Froumin, 175-197. Basingstoke, UK: Palgrave.

Civil.Ge. 2019. “Government to Help Prep Abkhazia, Tskhinvali Region Graduates for Universities.” April 17, 2019. https:// civil.ge/archives/302563 (Accessed July 9, 2020.)

Comai, Giorgio, and Bernardo Venturi. 2015. "Language and Education Laws in Multi-Ethnic de facto States: The Cases of Abkhazia and Transnistria.” Nationalities Papers 43 (6): 886-905.

Conciliation Resources. 2016. "The Realm of the Possible: Finding Ways forward in the Georgian-Abkhaz Context: Challenges in Education.” Discussion Paper. July. https://www.c-r.org/resource/realm-possible-education (Accessed July 9, 2020.)

Coppieters, Bruno. 2012. "Conflict Resolution after the 2008 Georgia-Russia War: The Taiwan and Kosovo Models as Tools for Mobilization and Comparison.” Nationalities Papers 40 (5): 677-701.

Coppieters, Bruno. 2018. “'Statehood,' 'de facto Authorities' and 'Occupation': Contested Concepts and the EU's Engagement in Its European Neighbourhood." Ethnopolitics 17 (4): 343-361. https://www.tandfonline.com/doi/full/10.1080/ 17449057.2018.1495361 (Accessed July 10, 2020.)

Coppieters, Bruno. 2019a. “Engagement without Recognition.” In Routledge Handbook of State Recognition, edited by Gëzim Visoka, John Doyle, and Edward Newman, 241-255. London and New York: Routledge. https://tandfbis.s3-us-west2.amazonaws.com/rt-files/docs/Open+Access+Chapters/9780815354871_oachapter19.pdf (Accessed July 9, 2020.)

Coppieters, Bruno. 2019b. "Abkhazia, Transnistria and North Cyprus: Recognition and Non-Recognition in Ceasefire and Trade Agreements.” The Ideology and Politics Journal 12 (1): 16-73. https://ideopol.org/wp-content/uploads/2019/11/ ENG.\%201.2.\%20Coppieters\%20FIN.pdf (Accessed November 11, 2020.)

de Waal, Thomas, and Sabine von Löwis. 2020. "Higher Education in Europe's Unrecognised Territories: Challenges and Opportunities." ZOiS Report 2. https://www.zois-berlin.de/publikationen/zois-report/?L=0 (Accessed July 9, 2020.)

De Wit, Hans, Fiona Hunter, Laura Howard, and Eva Egron-Polak. 2015. "Internationalisation of Higher Education." Brussels: Policy Department, Directorate General for Internal Policies, European Parliament. https://www.europarl.europa.eu/ RegData/etudes/STUD/2015/540370/IPOL_STU(2015)540370_EN.pdf (Accessed July 10, 2020.)

Dzhikirba, Salima, and Sebastian Relitz. 2020. "Strengthening Internationalization of Higher Education in Abkhazia: StatusQuo, Potentials, Challenges and Recommendations.” In Insights from Young Scholars and Peacebuilders from the Caucasus, edited by Sebastian Relitz, 66-80. Corridors Proceedings Vol. II. Berlin: Corridors.

Eastern Mediterranean University. 2021a. "Warwick-EMU Programs.” https://www.emu.edu.tr/en/prospective-students/war wick-emu-programs/1308 (Accessed July 6, 2021.)

Eastern Mediterranean University. 2021b. “Comparative Legal Systems Master's Program (without Thesis).” https://www. emu.edu.tr/en/programs/comparative-legal-systems-masters-program-without-thesis-joint-program-with-university-ofbologna/1510 (Accessed 6 July, 2021.)

ENIC-NARIC Networks. 2021. “About the ENIC-NARIC Networks.” https://www.enic-naric.net/index.aspx (Accessed July 6, 2021.)

ENQA. 2021. “About ENQA.” https://www.enqa.eu/about-enqa/ (Accessed July 6, 2021.)

EQAR. 2021. “Country Information: Kosovo ${ }^{\star ” ~ h t t p s: / / w w w . e q a r . e u / k b / c o u n t r y-i n f o r m a t i o n / c o u n t r y / ? i d=268 ~(A c c e s s e d ~ J u l y ~}$ 6, 2021.)

Estermann, Thomas. 2015. "University Autonomy in Europe." University Education, No. 3: 28-32. https://ir.kneu.edu.ua/ handle/2010/16987 (Accessed July 4, 2012.)

European Commission and High Representative of the European Union for Foreign Affairs and Security Policy. "Joint Staff Working Document: Implementation of the European Neighbourhood Policy in Georgia - Progress in 2014 and Recommendation for Actions." March 25, 2015. http://eeas.europa.eu/enp/pdf/2015/georgia-enp-report-2015_en.pdf. (Accessed July 9, 2020.)

European Higher Education Area and Bologna Process. 2021. http://www.ehea.info (Accessed July 6, 2021.)

European University Association. 2021. “Who We Are.” https://eua.eu/about/who-we-are.html (Accessed July 6, 2021.)

Fabry, Mikulas. 2012. "The Contemporary Practice of State Recognition: Kosovo, South Ossetia, Abkhazia, and Their Aftermath." Nationalities Papers 40 (5): 661-676.

Fearon, James D. 1999. "What Is Identity (As We Now Use the Word)?” Unpublished manuscript. Stanford, California: Stanford University. http://www.web.stanford.edu/group/fearon-research/cgi-bin/wordpress/wp-content/uploads/2013/ 10/What-is-Identity-as-we-now-use-the-word-pdf (Accessed October 22, 2020.)

Fischer, Sabine. 2010. “The EU's Non-Recognition and Engagement Policy towards Abkhazia and South Ossetia.” Seminar Reports. Seminar presented at the European Union Institute for Security Studies, Brussels, October 1-2. https://www.iss. europa.eu/sites/default/files/EUISSFiles/NREP_report.pdf (Accessed July 9, 2020.)

Geldenhuys, Deon. 2009. Contested States in World Politics. New York: Palgrave Macmillan.

Gerrits, André W. M., and Max Bader. 2016. "Russian Patronage over Abkhazia and South Ossetia: Implications for Conflict Resolution.” East European Politics 32 (3): 297-313.

Hamid, Linda. 2020. "Non-State Actors That Aspire to Be States: White Spots on the International Human Rights Protection Map?" In Human Rights in Times of Transition, edited by Kasey McCall-Smith, Andrea Birdsall, and Elisenda Casanas Adam, 216-241. Cheltenham, UK: Edward Elgar. 
Hammarberg, Thomas, and Magdalena Grono. 2017. Human Rights in Abkhazia Today (Report). Olof Palme International Center. July 2017. https://www.palmecenter.se/wp-content/uploads/2017/07/Human-Rights-in-Abkhazia-Today-reportby-Thomas-Hammarberg-and-Magdalena-Grono.pdf (Accessed July 9, 2020.)

Hsieh, Pasha. L. 2019. “The Quest for Recognition: Taiwan's Military and Trade Agreements with Singapore under the One-China Policy." International Relations of the Asia-Pacific 19 (1): 89-115.

International Association of Universities, ed. 2006, "World List of Universities and Other Institutions of Higher Education." Basingstoke, UK: Palgrave.

International Association of Universities, ed. 2010. International Handbook of Universities. Basingstoke, UK: Palgrave.

International Association of Universities. 2021a. "List of IAU Members." https://iau-aiu.net/List-of-IAU-Members?lang=en (Accessed July 6, 2021.)

International Association of Universities. 2021b. “IAU WHED: The World of Higher Education at Your Fingertips.” https:// www.whed.net/home.php (Accessed July 6, 2021.)

Jibladze. Elene. 2017. "Reforms for the External Legitimacy in the Post Rose Revolution Georgia. Case of University Autonomy." Hungarian Educational Research Journal 7 (1): 7-21.

Ker-Lindsay, James. 2012. The Foreign Policy of Counter Secession: Preventing the Recognition of Contested States. Oxford: Oxford University Press.

Kolstø, Pål. 2020. "Biting the Hand That Feeds Them? Abkhazia-Russia Client-Patron Relations.” Post-Soviet Affairs 36 (2): $140-158$.

Kove, Daur. 2018. “A Step to a Better Future.” Abkhaz Ministry of Foreign Affairs, April 5, 2018. http://mfaapsny.org/en/ allnews/news/statements_speeches/kommentariy-daura-kove-o-novoy-mirnoy-initsiative-pravitelstva-gruzii-shag-k-luch shemu-budushchemu-/?sphrase_id=75422 (Accessed July 6, 2021.)

Lauterpacht, Hersch. 2013. Recognition in International Law. Cambridge: Cambridge University Press.

Mäkinen, Sirke. 2016. "In Search of the Status of an Educational Great Power? Analysis of Russia's Educational Diplomacy Discourse.” Problems of Post-Communism 63 (3): 183-196.

Mirimanova, Natalia. 2018. "Opening the 'Ingur/i Gate' for Legal Business: Views from Georgian and Abkhaz Private Companies.” International Alert, March 2018. https://www.international-alert.org/publications/opening-inguri-gatelegal-business (Accessed March 1, 2021.)

National Erasmus + Office (NEO) Georgia. 2021. https://erasmusplus.org.ge/en/ug-in-georgia (Accessed July 9, 2020.)

Noutcheva, Gergana. 2020. “Contested Statehood and EU Actorness in Kosovo, Abkhazia and Western Sahara." Geopolitics 25 (2): 449-471.

OC Media. 2018. “Georgia Unveils ‘Unprecedented’ Peace Initiative for Abkhazia, South Ossetia,” April 4, 2018. https://ocmedia.org/georgia-unveils-unprecedented-peace-initiative-for-abkhazia-south-ossetia/ (Accessed July 6, 2021.)

Ofitsial'nyy sayt Prezident Respubliki Abkhaziya Sergey Bagapsh. 2008. “Abkhazskiy gosudarstvennyy universitet.” https:// web.archive.org/web/20080515231642/http://www.abkhaziagov.org/ru/state/culture/university.php (Accessed July 6, 2021.)

Olson, Lara, and Mira Sovakar. 2018a. Reducing Isolation in the Georgian-Abkhaz Context: Engaging the German Academic Exchange Service in the Limehouse Discussion Platform. London: Conciliation Resources.

Olson, Lara, and Mira Sovakar. 2018b. Promoting Collaboration and Mutual Understanding through English Language Education in Abkhazia. London: Conciliation Resources.

Pandey, I. M. 2004. “Governance of Higher Education Institutions.” Vikalpa: The Journal for Decision Makers 29 (2): 79-84. https://journals.sagepub.com/doi/pdf/10.1177/0256090920040207 (Accessed March 1, 2021.)

Pegg, Scott. 1998. International Society and the de facto State. Aldershot, UK: Ashgate.

Piro, Joseph M. 2016. Revolutionizing Global Higher Education Policy: Innovation and the Bologna Process. Oxfordshire and New York: Routledge.

Polandov, Demis. 2013. “Kak vyyti iz situatsii neponimaniya?” Ekho Kavkaza, February 25, 2013. https://www.ekhokavkaza. com/a/24912405.html (Accessed July 11, 2020.)

Prelz Oltramonti, Giulia. 2020. "The Viability of De Facto States: Cases from the Caucasus and the Horn of Africa." In Perspectives on Secession. Frontiers in International Relations, edited by Martin Riegl and Bohumil Doboš, 93-107. Cham, Switzerland: Springer.

Prezident Respubliki Abkhaziya. 2020. UKAZ ob utverzhdenii kontseptsii vneshney politiki Respubliki Abkhaziya. December 4. http://presidentofabkhazia.org/upload/iblock/e3b/KONTSEPTSIYA-Vneshey-politiki.pdf (Accessed July 6, 2021.)

RIA Novosti. 2014. “Lidery RF i Abkhazii podpisali dogovor o strategicheskom partnerstve.” November 24, 2014. https://ria.ru/ 20141124/1034869132.html (Accessed July 9, 2020.)

Shakryl, Asida. 2019. Yezhegodnyy doklad o deyatel'nosti Upolnomochennogo po pravam cheloveka v Respublike Abkhaziya za 2018 - 2019 gg., https://ombudsmanra.org/upload/iblock/f9b/f9bcad983b2dbaafd39cfb8886290fa2.pdf (Accessed July 9, 2020.)

Shariya, Vitaliy. 2013. "Nikakikh semafornykh signalov abkhazskaya storona nikomu ne podavala." Ekho Kavkaza, March 22, 2013, https://www.ekhokavkaza.com/a/24936492.html (Accessed July 9, 2020.) 
Strömbom, Lisa. 2014. “Thick Recognition: Advancing Theory on Identity Change in Intractable Conflicts.” European Journal of International Relations 20 (1): 168-191.

Tass. 2017. “Rossiya i Abkhaziya podpisali soglasheniye o vzaimnom priznanii obrazovaniya.” December 19, 2017. https:// tass.ru/obschestvo/4824703 (Accessed July 9, 2020.)

Visoka, Gëzim, and John Doyle. 2015. Neo-Functional Peace: The European Union Way of Resolving Conflicts. JCMS: Journal of Common Market Studies 54 (4): 862-877.

Wils, Oliver, Ulrike Hopp, Norbert Ropers, Luxshi Vimalarajah, and Wolfram Zunzer. 2006. The Systemic Approach to Conflict Transformation. Berlin: Berghof Foundation for Peace Support.

Wittke, Cindy. 2020. “The Politics of International Law in the Post-Soviet Space: Do Georgia, Ukraine, and Russia 'Speak' International Law in International Politics Differently?” Europe-Asia Studies 72 (2): 180-208.

Wydra, Doris. 2020. "Between Normative Visions and Pragmatic Possibilities: The EUropean Politics of State Recognition." Geopolitics 25 (2): 315-345.

Yevraziyskaya assotsiatsiya universitetov. 2021. “About EAU.” http://www.eau-msu.ru/eng/about (Accessed July 6, 2021.)

Cite this article: Coppieters, B. 2023. A Struggle over Recognition and Nonrecognition: The Internationalization of the Abkhaz State University. Nationalities Papers 51: 469-490, doi:10.1017/nps.2021.48 